\title{
Physical and physicochemical stability evaluation of cosmetic formulations containing soybean extract fermented by Bifidobacterium animalis
}

\author{
Rafael Pinto Vieira, Alessandra Ribeiro Fernandes, Telma Mary Kaneko, Vladi Olga Consiglieri, \\ Claudinéia Aparecida Sales de Oliveira Pinto, Claudia Silva Cortez Pereira, André Rolim Baby, \\ Maria Valéria Robles Velasco*
}

Laboratory of Cosmetology, Department of Pharmacy, Faculty of Pharmaceutical Sciences, University of São Paulo

\begin{abstract}
Peel off facial masks, based on polyvinyl alcohol (PVA), are formulations that, after application and drying, form an occlusive film over the face. After removing, they provide cleanness, tensor and moisturizing effects, removing dead cells, residues and other materials deposited on the stratum corneous. The soybean extract fermented by Bifidobacterium animalis has sugars, amino acids, peptides, proteins and free isoflavonoids in high concentrations, when compared to the unfermented extract, providing benefits to the cosmetic formulations like anti-aging effect, moisture, tensor action and emollience. The cosmetic bases of peel off facial masks, added with $5.0 \% \mathrm{w} / \mathrm{w}$ of fermented soybean extract, were submitted to Preliminary and Accelerated Stability Studies. Eight (8) preparations were evaluated in several conditions of temperature $\left(-10.0,5.0,22.0\right.$ and $45.0^{\circ} \mathrm{C}$ ) and time (maximum of 15 days), comparing the results with the initial condition ( $48 \mathrm{~h}$ after preparation). The variables observed were: organoleptic characteristics, $\mathrm{pH}$ and appearing viscosity value and film drying time. The preparation containing $17.0 \% \mathrm{w} / \mathrm{w}$ of PVA and $0.5 \% \mathrm{w} / \mathrm{w}$ of guar gum was selected between the eight preparations initially prepared, because it presented the best performance in the stability test, being recommended storage at low temperatures $\left(5.0^{\circ} \mathrm{C}\right)$.
\end{abstract}

Uniterms: Cosmetic formulations/physical and physicochemical stability. Facial mask peel off. Polyvinyl alcohol. Soybean extract. Bifidobacterium animalis/fermentation.

\begin{abstract}
As máscaras faciais peel off a base de álcool polivinílico (PVA) são formulações que, após a aplicação e secagem, formam um filme oclusivo sobre a face e, após sua remoção, conferem limpeza, ação tensora e hidratação à pele, retirando células mortas do estrato córneo, resíduos e outros materiais depositados. $\mathrm{O}$ extrato de soja fermentado por Bifidobacterium animalis possui açúcares, aminoácidos, peptídeos, e alto teor de isoflavonas na forma livre, quando comparado ao leite não fermentado, propiciando benefícios às formulações cosméticas, como ação antienvelhecimento, hidratação, efeito tensor e emoliência. As bases cosméticas de máscaras faciais peel off, acrescidas de extrato de soja fermentado $5,0 \% \mathrm{p} / \mathrm{p}$, foram submetidas aos ensaios de Estabilidade Preliminar e Acelerada, avaliando-se 8 preparações em diversas condições de temperatura $\left(-10,0 ; 5,0 ; 22,0\right.$ e $\left.45,0^{\circ} \mathrm{C}\right)$ e tempo (máximo de 15 dias), em relação à condição inicial (48 h após o preparo). As variáveis observadas envolveram: características organolépticas, valor de $\mathrm{pH}$, viscosidade aparente e tempo de secagem do filme. A preparação contendo $17,0 \% \mathrm{p} / \mathrm{p}$ de PVA e $0,5 \% \mathrm{p} / \mathrm{p}$ de goma guar foi a selecionada dentre as oito preparações elaboradas inicialmente, por ter apresentado melhor desempenho no teste de estabilidade, sendo recomendado o armazenamento em temperatura reduzida $\left(5,0^{\circ} \mathrm{C}\right)$.
\end{abstract}

Unitermos: Formulações cosméticas/estabilidade física e físico-química. Máscara facial peel off. Álcool polivinílico. Extrato de soja. Bifidobacterium animalis/fermentação.

\footnotetext{
*Correspondence: M. V. R. Velasco. Laboratório de Cosmetologia, Departamento de Farmácia, Faculdade de Ciências Farmacêuticas, Universidade de São Paulo, Av. Prof. Lineu Prestes, n. 580, bl. 13/15, Cidade Universitária, 05508-900 - São Paulo - SP, Brasil. E-mail: mvrobles@usp.br
} 


\section{INTRODUCTION}

The use of facial masks is found in the Antiquity (Wilkinson, Moore, 1982). Nowadays, the interest regarding these topic formulations was re-gained due to several attributed effects, like: deep cleanness, tonification, astringency, moisture, emollience (softening and soothing) and tensor action (Bonadeo, 1982; Draelos, 1999; Martine et al., 1995; Poucher, 1991; Nishikawa et al., 2007).

Peel off facial masks are constituted of polyvinyl alcohol (PVA) or polyvinyl acetate, utilized as film formers (Wilkinson, Moore, 1982; Aranha, Lucas, 2001). They produce occlusion and tensor action after drying, then, making the skin softer to touch. If an active substance is added to the formulation its action is increased (Baby et al., 2004; DeNaverre, 1975).

The determinant step in the development of a cosmetic formulation involves stability study, with the objective of predicting physical, physicochemical, chemical and microbiological alterations that may occur since its manufacturing, until the end of its expiration date (Brasil, 2004). Besides, this study allows the evaluation of the cosmetic product performance, safety and efficacy and contributes for its development time reduction which is highly required by the market and the consumers. The stability test guides the development of cosmetic formulations, providing information for preparation improvements, in case of instability manifestations and/or incompatibility among ingredients (Brasil, 2004; Nishikawa et al., 2007; Baby et al., 2008).

For the stability test to be meaningful, it is important to establish variables that will be evaluated, defining the acceptance criteria and/or the methods able to measure the attribute variations over time. The choice of the tests to be performed is responsibility of the researcher and the criteria and decisions are based on the type of cosmetic product related to the scientific literature, guides and Official Compendiums, once each formulation has particular characteristics of ingredients and cosmetic forms. These criteria must take also into account the main product characteristics, because these attributes must remain with no alteration - or with alterations that do not compromise the performance and presentation of product (Barel et al., 2001).

The peel off facial masks may be used as vehicles for active substances (DeNaverre, 1975; Magalhães, 2000), like the soy milk fermented by Bifidobacterium animalis, which presents as attributes the antioxidant and the moisture properties, indicating a cosmetic potential (Baumann, Lazarus, 2001; Lupo, 2001; Myiazaki et al. 2002; Otieno et al., 2006; Prakash et al., 2007).
In this study, the physical and physicochemical stability of peel off facial mask formulations containing fermented soy milk, and their respective cosmetic bases, were compared by Preliminary and Accelerated Stability studies and formulation performance, evaluated by in vitro drying time.

\section{MATERIAL AND METHODS}

\section{Formulations - composition}

Ingredients utilized in formulations: polyvinyl alcohol, moisture agent (glycerin, propylenoglycol or butylenoglycol), dimethyl dimethyl hydantoin/ iodopropynyl butylcarbamate, self-emulsifying base, silicone glycol copolymer, ethoxylated and propoxylated cetyl alcohol, blue colorant, essence, deodorized ethanol, tetrasodium EDTA and water. Thirty six (36) cosmetic bases were developed, varying the proportion of five components, thus, selecting the ones with best performance according to the Preliminary Stability Test for future incorporation of the soybean extract fermented by Bifidobacterium animalis (total of 8 preparations). For the Accelerated Stability Study, the two formulations with best performance on previous test, were selected.

\section{Screening Study}

Thirty six (F1 to F36) cosmetic bases were prepared without the addition of soybean extract fermented by Bifidobacterium animalis, varying the concentration of polyvinyl alcohol (film former - 12,0 and 15,0\% w/w), moisture agent $(0.0,6.0$ and $8.0 \% \mathrm{w} / \mathrm{w})$, self-emulsifying base $(0.0,1.0$ and $2.0 \% \mathrm{w} / \mathrm{w})$, silicone glycol copolymer $(0.0,1.0$ and $2.0 \% \mathrm{w} / \mathrm{w})$ and ethoxylated and propoxylated cetyl alcohol $(0.0$ and $2.0 \% \mathrm{w} / \mathrm{w})$. It was prepared $100.0 \mathrm{~g}$ of each formulation, according to standardized method that consists on the dispersion of the PVA previously incorporated to the moisture agent in distilled water at $80.0-90.0^{\circ} \mathrm{C}$, with constant mechanic agitation (Aranha, Lucas, 2001; Chiellini et al., 2003). After cooling the preparation bellow $40.0^{\circ} \mathrm{C}$, it was added in sequence and separately: ethanol, preservative (dimethyl dimethyl hydantoin/ iodopropynyl butylcarbamate), tetrasodium EDTA, essence (incorporated to the surfactant and silicon) and, finally, the blue colorant. The mass of final preparation was completed with water.

\section{Preliminary Stability Study}

For the Preliminary Stability Study, eight (8) formulations were prepared containing the soybean extract fermented by Bifidobacterium animalis, based on the prepa- 
ration that presented the best performance in the previously mentioned screening study. The concentration of polyvinyl alcohol (film former) was varied (15.0, 17.0, 18.0 and $20.0 \% \mathrm{w} / \mathrm{w}$ ) and $0.5 \% \mathrm{w} / \mathrm{w}$ or none of a new component, guar gum (thickener), was added targeting to reduce the in vitro drying time of the formulations. The other components remained unaltered in all formulations. The preparing procedure was identical to that of the cosmetic bases, adding the guar gum after the cooling of the polymer dispersed in water. The soybean extract $(5.0 \% \mathrm{w} / \mathrm{w})$ was added at the end of preparation, after cooling the base and before completing with water the preparation mass .

Elapsed 48 hours from production for formulation stabilization, and considering this time as initial $\left(\mathrm{t}_{0}\right)$, cosmetic bases and formulations were wrapped in packaging materials composed of opaque white polyethylene with declared capacity for $50 \mathrm{~g}$ and submitted to the conditions for each test (Baby, 2005; Brasil, 2004; Contreras et al., 2001, Pinto, 2005; Zague, 2007).

All cosmetic bases and formulation samples (triplicate) were submitted to Centrifugation (5.0 g at 1000 , 2000 and $3000 \mathrm{rpm} / 15$ minutes); Thermal Stress (10.0 g in water bath between 40.0 to $80.0^{\circ} \mathrm{C}$, raising from 10.0 to $10.0^{\circ} \mathrm{C}$, for 30 minutes in each temperature value); and Oven $\left(50.0 \pm 2.0^{\circ} \mathrm{C} / 72\right.$ hours) (Baby, 2005; Brasil, 2004; Pinto, 2005; Baby et al., 2007).

\section{Accelerated Stability Study}

Samples, in duplicate, from the two best formulations selected in the Preliminary Stability Study were submitted to this Study. The evaluations considered several temperature conditions and times of analysis. Initially, they were evaluated after t 0 ( 48 hours after preparation) in the conditions: Low Temperature $\left(5.0 \pm 1.0^{\circ} \mathrm{C}\right)$, Freezer $\left(-10.0 \pm 1.0^{\circ} \mathrm{C}\right)$, Room Temperature $\left(22.0 \pm 2.0^{\circ} \mathrm{C}\right)$ and Oven $\left(45.0 \pm 2.0^{\circ} \mathrm{C}\right)-$ analysis at $1^{\text {st }}, 3^{\text {rd }}, 7^{\text {th }}$ and $15^{\text {th }}$ days and Freezing/Defrosting Cycles $\left(45.0 \pm 2.0^{\circ} \mathrm{C} /-5.0 \pm\right.$ $2.0^{\circ} \mathrm{C}$ - analysis at $6^{\text {th }}$ and $12^{\text {th }}$ days $)$.

\section{Variables analyzed and acceptance criteria}

The criteria were established by the analyst and are described, as follows, comparing the results obtained with the initial condition $\left(\mathrm{t}_{0}\right)$ (Baby, 2005; Brasil, 2004; Pinto, 2005; Baby et al., 2007; Zague, 2007).

For the Screening and Preliminary Stability Studies were evaluated: organoleptic characteristics, $\mathrm{pH}$ value and performance test - drying time. For the Accelerated Stability Study the viscosity determination was added, besides all the evaluations mentioned.

\section{Organoleptic characteristics}

Color: N-Normal / M-Modified / IM-Intensely modified Odor: N - Normal/ M - Modified / IM - Intensely modified Aspect: N-Normal/M-Modified / IM-Intensely modified Spreadability and touch: A - pleasant touch, easy application/ D - unpleasant touch, sticky / MD - very unpleasant touch, very sticky, compromises skin application.

\section{$\mathrm{pH}$ Value}

As acceptance criteria, formulations with $\mathrm{pH}$ value variations higher than $15 \%$, comparing with the initial value, were reproved, considering the $\mathrm{pH}$ of isoelectric point of soy proteins is around 4.5 (precipitation may occur), and values beyond the range of 2 to 10 cause degradation of the proteins present in the soybean extract fermented by Bifidobacterium animalis (Genovese et al., 2006).

\section{Performance test - drying and film formation}

This methodology was developed and standardized, based on the use of commercial product. The test was performed after 48 hours after the preparation of the cosmetic bases and formulations of peel off facial masks ( $\mathrm{t} 0$ ).

Samples, in triplicate, containing around $0.7 \mathrm{~g}$ of cosmetic base were weighted and spread using a painter's brush, over an area of $5.0 \times 2.5 \mathrm{~cm}$ in a glass slide, forming an uniform thin layer of about $1 \mathrm{~mm}$, to mimic the film formed at the face after application of the peel off mask. The glass slide was put in oven at $36.5 \pm 2.0^{\circ} \mathrm{C}$ for $1 \mathrm{~h}$, simulating the body temperature. The formulations were monitored during $10 \mathrm{~min}$, until the drying process was completed and allowed the complete removal of the film from the glass slide.

\section{Apparent Viscosity}

The peel off facial masks submitted to the Accelerate Stability Study were analyzed in duplicate in Fungilab ${ }^{\circledR}$ ViscoStar-R with a device for small samples (spindles TR10 and TR11), at $6 \mathrm{rpm}$. The results obtained at initial evaluation $(\mathrm{t} 0)$ were considered reference value $(100 \%)$ to calculate the observed variations (Maia, 2002). The apparent viscosity values ( $\mathrm{cP}$, centiPoise) were registered after 3 minutes of agitation at room temperature (Nishikawa et al., 2007).

\section{RESULTS AND DISCUSSION}

\section{Screening Study}

After the preparation of thirty six (36) cosmetic bases and performing the Screening Study, the base F35 was selected as the best in performance. The quali and 
quantitative composition and the results of this Study are described in Tables I e II, respectively.

The evaluation of organoleptic characteristics and $\mathrm{pH}$ values results show that the base $\mathrm{F} 35$ was appropriate to continue the studies. However, in the in vitro drying time evaluation, it presented results above the recommended range for peel off facial masks (10 to 30 minutes) (Martine et al., 1995, Charlet, 1996). Therefore, for the subsequent studies, besides adding fermented soybean extract to the base, it was evaluated the influence of polyvinyl alcohol concentration and it was added a new component, the guar gum, in order to reduce the drying time of in vitro film formation, improving the performance of the previous selected formulation.

TABLE I - Composition of cosmetic base F35 selected in the Screening Study

\begin{tabular}{lc}
\hline COMPONENTS & $\%(\mathrm{w} / \mathrm{w})$ \\
Aqueous Phase & \\
\hline Polivynil Alcohol (PVA) & 15.0 \\
Glicerin & 6.0 \\
Distilled water q.s.p. & 100.0 \\
\hline Complementary Phase & \\
\hline DMDM Hydantoin/ & 0.5 \\
Iodopropynyl Butylcarbamate (IPBC) & \\
IPBC & 2.0 \\
Ethoxylated and Propoxylated Cetyl Alcohol & 0.1 \\
Blue colorant & 8.0 \\
Deodorized alcohol & 0.05 \\
Essence & 0.1 \\
Tetrasodium EDTA &
\end{tabular}

\section{Preliminary Stability Study}

From the base F35, 8 formulations containing soybean extract fermented by Bifidobacterium animalis were prepared, keeping this codification added by a number referring to the polyvinyl alcohol (PVA) proportion (17.0, 18.0 and $20.0 \% \mathrm{w} / \mathrm{w}$ ) and $\mathrm{G}$ referring to the presence of guar gum $0,5 \% \mathrm{w} / \mathrm{w}$.

The obtained results respecting organoleptic characteristics and $\mathrm{pH}$ values are described in Table III. The variable Aspect indicated supernatant liquid formation for the preparations $\mathrm{F} 35 / 15$ and F35/17, besides more fluidity during the Thermal Stress test, indicated by the results M/IM. Color alteration was not observed in any preparation, indicating good stability, mainly in high temperature conditions and compatibility with the colorant and other formulation components. The results of Odor indicated reduction of the fragrance intensity in the Thermal Stress test for all preparations. The formulations evaluated in the Application and Touch showed that those with $20 \% \mathrm{w} / \mathrm{w}$ of PVA (F35/20 and F35/20G), the higher polymer concentration presented high consistency and compromised spreadability, reflecting a negative evaluation (MD - very unpleasant touch, sticky), probably because of inadequate PVA proportion. The best performance formulations in the Application and Touch evaluation were those with intermediate PVA concentrations (F35/17G and $\mathrm{F} 35 / 18,17$ and $18 \%$ polymer $\mathrm{w} / \mathrm{w}$, respectively). The alterations observed for the organoleptic characteristics in the Thermal Stress and Oven $\left(50.0 \pm 2.0^{\circ} \mathrm{C}\right)$ tests were accepted in the Preliminary Study, considering the drastic conditions that formulations were submitted to (Brasil, 2004).

TABLE II - Evaluation of organoleptic characteristics, pH value and drying time of the peel off facial mask cosmetic base (F35) in the Screening Study

\begin{tabular}{lccccccccc}
\hline Cosmetic Base & \multicolumn{1}{c}{ Parameter evaluated } & \multicolumn{2}{c}{ Application } & pH & pH & Drying time \\
& Test & Aspect & Color & Odor & Touch & Bf. & Af. & variation(\%) & (min) \\
\hline \multirow{3}{*}{ F35 } & C & N & N & N & A & Na & Na & 0 & \\
& T S & N & N & N & A & 7.2 & 6.7 & 6.9 & 36.7 \\
& E 50 & N & N & N & A & 7.2 & 6.8 & 5.6 & \\
\hline
\end{tabular}

Legend: Cosmetic Base: group of initial preparations (F1 to F36); Test: C - Centrifugation; TS - Thermal Stress; E 50 - Oven $50 \pm 2.0^{\circ} \mathrm{C} / 72$ hours; Aspect: $\mathbf{N}$ - Normal; $\mathbf{M}$ - Modified; IM - Intensely modified; Color: N - Normal; M - Modified; IM Intensely modified; Odor: N - Normal; M-Modified; IM - Intensely modified; Application and Touch: A - Pleasant touch, easy skin application (spreadability); D - Unpleasent touch, sticky, relative difficulty to apply on skin (spreadability); MD Very unpleasant touch, very sticky, compromises skin application; $\mathbf{p H}$ : Na - not applicable; Bf.: after 48 hours from preparation (t0); Af: after test condition. 
TABLE III - Organoleptic characteristics and $\mathrm{pH}$ values evaluation of the peel off facial mask formulations (modifications from the F35 base) in the Preliminary Stability Study

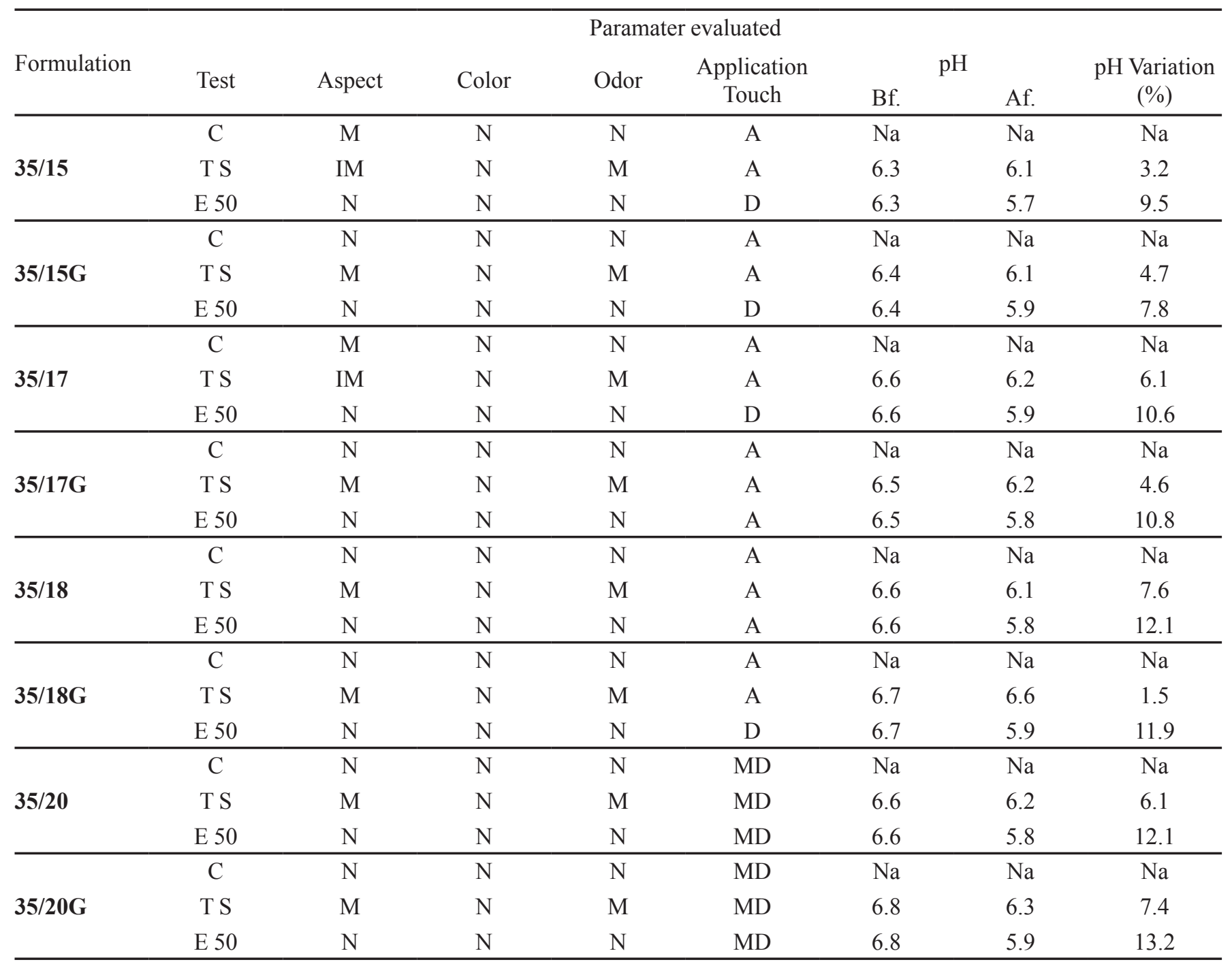

Legend: Formulation: preparations resulted from base F35 alterations; Test: C - Centrifugation; TS - Thermal Stress; E 50 Oven $50.0 \pm 2.0^{\circ} \mathrm{C} / 72$ hours; Aspect: $\mathbf{N}$ - Normal; $\mathbf{M}$ - Modified; IM - Intensely modified; Color: N - Normal; $\mathbf{M}$ - Modified; IM - Intensely modified; Odor: N - Normal; M - Modified; IM - Intensely modified; Application and Touch: A - Pleasant touch, easy skin application (spreadability); D - Unpleasent touch, sticky, relative difficulty to apply on skin (spreadability); MD - Very unpleasant touch, very sticky, compromises skin application; pH: Na - not applicable; Bf.: after 48 hours from preparation (t0); Af: after test condition.

\section{In vitro drying time and film formation}

The in vitro drying time means (triplicate) for the formulations modified from F35 base are presented in Figure 1.

In accordance to the data presented, the formulations $35 / 17,35 / 17 \mathrm{G}, 35 / 18,35 / 18 \mathrm{G}$ and $35 / 20$ presented the best performance on the in vitro drying time test, which means they formed a resistant film easily removed from the glass slides at maximum time of $30.0 \mathrm{~min}$ and the formulation
$35 / 20 \mathrm{G}$ presented the lowest value (26.7 $\mathrm{min})$. The reduced in vitro drying time is indispensable pre-requisite to the use acceptability of peel off masks (Wilkinson, Moore, 1982), just as the organoleptic characteristics, mainly the Application e Touch, because of the importance of mask adherence at the local of application.

Considering the results of in vitro drying time, organoleptic characteristic evaluation and $\mathrm{pH}$ values, and that some modifications are accepted in drastic condition of temperature, the formulations $35 / 18$ and $35 / 17 \mathrm{G}$ were se- 
TABELE IV - Evaluation of the organoleptic characteristics, $\mathrm{pH}$ and apparent viscosity of formulation $\mathbf{F 3 5} / \mathbf{1 7 G}$, in the Accelerated Stability Study

\section{Storage Conditions}

\begin{tabular}{|c|c|c|c|c|c|c|c|c|c|c|c|c|c|c|c|c|}
\hline \multirow[t]{2}{*}{ Parameters } & \multirow[t]{2}{*}{$\mathbf{t}_{0}$} & \multicolumn{3}{|c|}{ G } & \multicolumn{3}{|c|}{ T.A. } & \multicolumn{3}{|c|}{$\begin{array}{c}F \\
\text { time (days) }\end{array}$} & \multicolumn{2}{|c|}{$\mathrm{C}$} & \multicolumn{4}{|c|}{$\mathrm{E} 45^{\circ}$} \\
\hline & & $3^{0}$ & $7^{0}$ & $15^{\circ}$ & $3^{\circ}$ & $7^{0}$ & $15^{\circ}$ & $3^{\circ}$ & $7^{0}$ & $15^{\circ}$ & $6^{\circ}$ & $12^{\circ}$ & $1^{\circ}$ & $3^{\circ}$ & $7^{\circ}$ & $15^{\circ}$ \\
\hline \multicolumn{17}{|c|}{ Formulation $35 / 17 \mathrm{G}$} \\
\hline $\mathrm{pH}$ & 6.7 & 6.6 & 6.5 & 6.5 & 6.3 & 6.3 & 6.2 & 6.6 & 6.4 & 6.5 & 5.8 & 5.8 & 6.2 & 5.9 & 5.7 & 5.7 \\
\hline Aspect & $\mathrm{N}$ & $\mathrm{N}$ & $\mathrm{N}$ & M & $\mathrm{N}$ & $\mathrm{N}$ & $\mathrm{N}$ & $\mathrm{N}$ & $\mathrm{N}$ & M & $\mathrm{N}$ & $\mathrm{M}$ & $\mathrm{N}$ & $\mathrm{N}$ & $\mathrm{N}$ & $\mathrm{N}$ \\
\hline Odor & $\mathrm{N}$ & $\mathrm{N}$ & $\mathrm{N}$ & $\mathrm{N}$ & $\mathrm{N}$ & $\mathrm{N}$ & $\mathrm{N}$ & $\mathrm{N}$ & $\mathrm{N}$ & $\mathrm{N}$ & $\mathrm{N}$ & $\mathrm{M}$ & $\mathrm{N}$ & $\mathrm{N}$ & $\mathrm{N}$ & M \\
\hline Color & $\mathrm{N}$ & $\mathrm{N}$ & $\mathrm{N}$ & $\mathrm{N}$ & $\mathrm{N}$ & $\mathrm{N}$ & $\mathrm{N}$ & $\mathrm{N}$ & $\mathrm{N}$ & $\mathrm{N}$ & $\mathrm{N}$ & $\mathrm{N}$ & $\mathrm{N}$ & $\mathrm{N}$ & $\mathrm{N}$ & $\mathrm{N}$ \\
\hline Application/ & A & A & A & $\mathrm{D}$ & A & A & A & $\mathrm{D}$ & $\mathrm{D}$ & $\mathrm{D}$ & $\mathrm{A}$ & A & A & A & A & $\mathrm{A}$ \\
\hline
\end{tabular}

Touch

Viscosity $\quad 856001146001225501134001052501026501056009640012800013030083450 \quad 97850 \quad 87100845008645082100$

Legend: Test: $\mathbf{G}$ - Low Temperature $\left(5.0 \pm 1.0^{\circ} \mathrm{C}\right)$; T.A. - Room Temperature $\left(22.0 \pm 2.0^{\circ} \mathrm{C}\right) ; \mathbf{E} 45$ - Oven $\left(45.0 \pm 2.0^{\circ} \mathrm{C}\right) ; \mathbf{C}$ - Freezing/Defrosting Cycles $\left(45.0 \pm 2.0{ }^{\circ} \mathrm{C} /-10.0 \pm 1.0^{\circ} \mathrm{C}\right) ; \mathbf{F}$ - Freezer $\left(-10.0 \pm 1.0{ }^{\circ} \mathrm{C}\right)$; Aspect: $\mathbf{N}$ - Normal; $\mathbf{M}$ - Modified; IM - Intensely Modified; Color: N - Normal; M - Modified; IM - Intensely Modified; Odor: N - Normal; M - Modified; IM - Intensely Modified; pH - pH value; Viscosity: values measured in cP, using TR 11 needle and 6 rpm velocity; Application e Touch: A - Pleasant touch, easy skin application (spreadability); D - Unpleasant touch, sticky, relative difficulty to apply on skin (spreadability); MD - Very unpleasant touch, very sticky, compromises skin application;

TABLE V - Evaluation of the organoleptic characteristics, $\mathrm{pH}$ and apparent viscosity of formulation $\mathbf{F 3 5} / \mathbf{1 8}$, in the Accelerated Stability Study

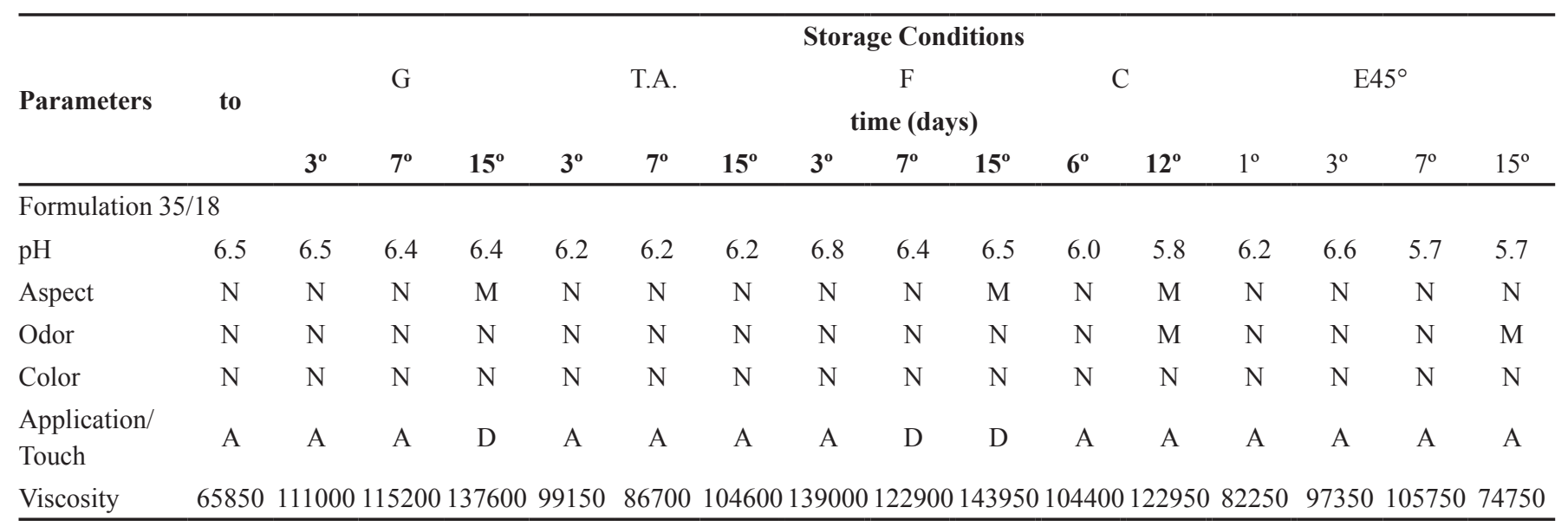

Legend: Test: $\mathbf{G}$ - Low Temperature $\left(5.0 \pm 1.0^{\circ} \mathrm{C}\right)$; T.A. - Room Temperature $\left(22.0 \pm 2.0^{\circ} \mathrm{C}\right) ; \mathbf{E 4 5}-$ Oven $\left(45.0 \pm 2.0^{\circ} \mathrm{C}\right) ; \mathbf{C}$ - Freezing/Defrosting Cycles $\left(45.0 \pm 2.0^{\circ} \mathrm{C} /-10.0 \pm 1.0^{\circ} \mathrm{C}\right) ; \mathbf{F}$ - Freezer $\left(-10.0 \pm 1.0{ }^{\circ} \mathrm{C}\right)$; Aspect: $\mathbf{N}$ - Normal; M - Modified; IM - Intensely Modified; Color: N - Normal; M - Modified; IM - Intensely Modified; Odor: N - Normal; M - Modified; IM - Intensely Modified; pH - pH value; Viscosity: values measured in cP, using TR 11 needle and 6 rpm velocity; Application e Touch: A - Pleasant touch, easy skin application (spreadability); D - Unpleasant touch, sticky, relative difficulty to apply on skin (spreadability); MD - Very unpleasant touch, very sticky, compromises skin application.

lected to the Accelerated Stability Study. The 35/18G, 35/20 e $35 / 20 \mathrm{G}$ formulations were excluded of the research, as they showed poor spreadability due to their very high consistency (high percentage of PVA in the formulations). The 35/17 was excluded because its intense modifications during the Thermal Stress. Between the F35/18 and F35/17G formulations, the second one presented greater stability in the performed tests, associated to small variations in the in vitro drying time, in comparison to F35/18, being so F35/17G the formulation indicated for cosmetic use. 


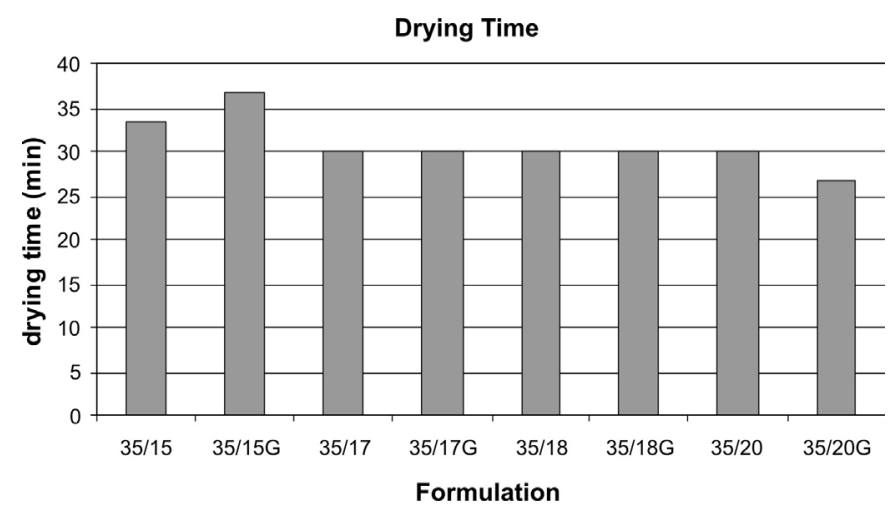

FIGURE 1 - Mean of in vitro drying time (min-triplicate) of the formulations obtained from the modifications in the peel off facial mask F35, in the condition of Oven $\left(36.5 \pm 1.0^{\circ} \mathrm{C}\right)$.

\section{Accelerated Stability Study}

The results obtained from organoleptic characteristics of the formulations $35 / 17 \mathrm{G}$ and $35 / 18$, $\mathrm{pH}$ value determination and apparent viscosity from the Accelerated Stability Study are described in the Tables IV and V and Figures 2, 3, 4, 5, 6 and 7. The result of drying time is represented at the Figure 8.

After analyzing the results from Tables IV and V, the Aspect evaluation showed that the formulation F35/17G presented higher consistency at the $15^{\text {th }}$ day (visual observation) for the Low Temperature and Freezer conditions, and at the $12^{\text {th }}$ day for the Freezing/Defrosting Cycles. This fact was confirmed by the raise in the apparent viscosity until $52 \%$ in the Freezer condition (Figure 6). The formulation $\mathrm{F} 35 / 18$ also presented higher consistency at the $15^{\text {th }}$ day (visual observation) for the Low Temperature and Freezer conditions and at the $12^{\text {th }}$ day for Freezing/Defrosting Cycles, also associated to the apparent viscosity variations, although with even higher observed values than the ones for the formulation $\mathrm{F} 35 / 17 \mathrm{G}$, reaching $119 \%$ of variation in the Freezer condition (Figure 6). Color alterations were not observed in the preparations, which indicated adequate

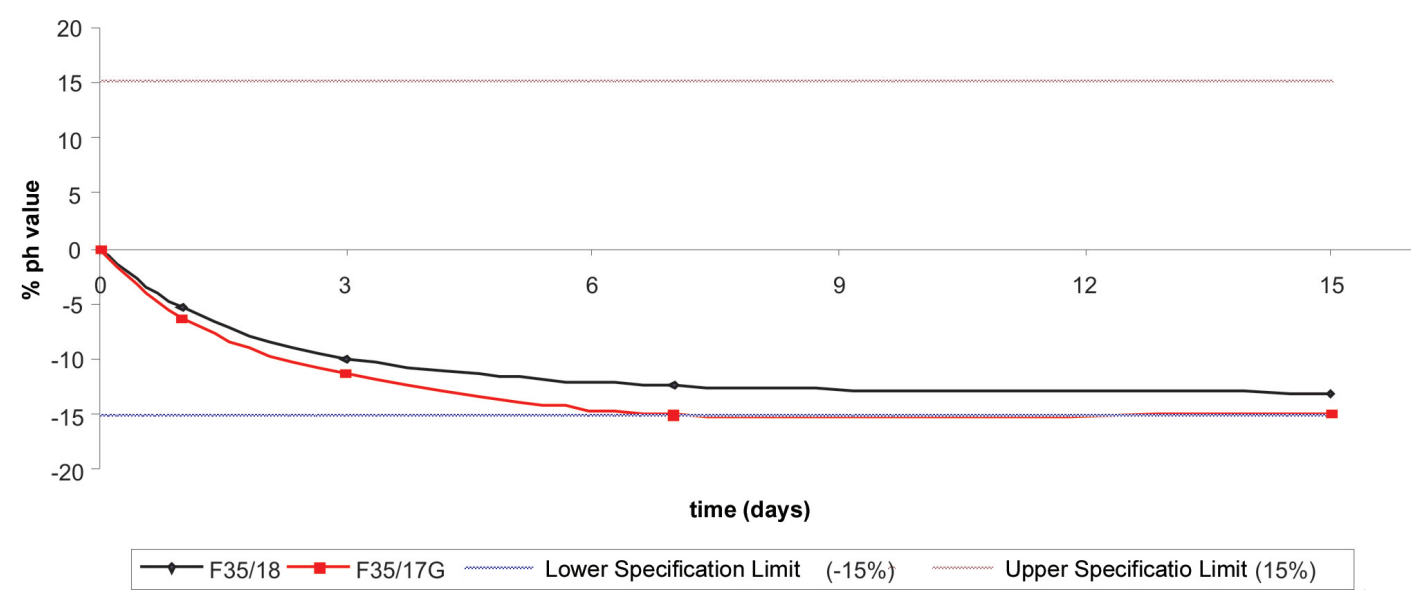

FIGURE 2 - Percentage variation of $\mathrm{pH}$ value for the test formulations $\mathbf{F 3 5} / \mathbf{1 8}$ and $\mathbf{F 3 5 / 1 7 G}$ in the Oven $\left(45.0 \pm 2.0^{\circ} \mathrm{C}\right)$ storage condition in the Accelerated Stability Study.

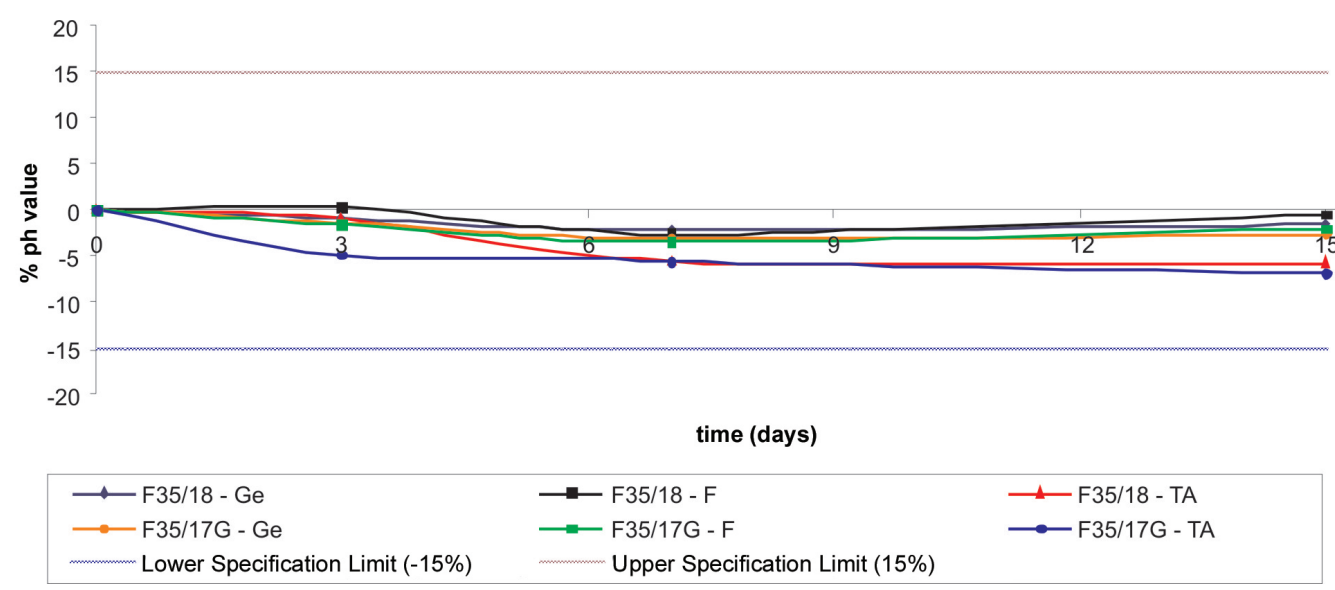

FIGURE 3 - Percentage variation of $\mathrm{pH}$ value for the test formulations $\mathbf{F 3 5} / \mathbf{1 8}$ and $\mathbf{F 3 5} / \mathbf{1 7 G}$ in the Refrigerator $\left(\mathrm{Ge}-5.0 \pm 1.0^{\circ} \mathrm{C}\right)$, Freezer $\left(\mathrm{F}--10.0 \pm 1.0^{\circ} \mathrm{C}\right)$ and Room Temperature $\left(\mathrm{TA}-22.0 \pm 2.0^{\circ} \mathrm{C}\right)$ storage conditions in the Accelerated Stability Study 


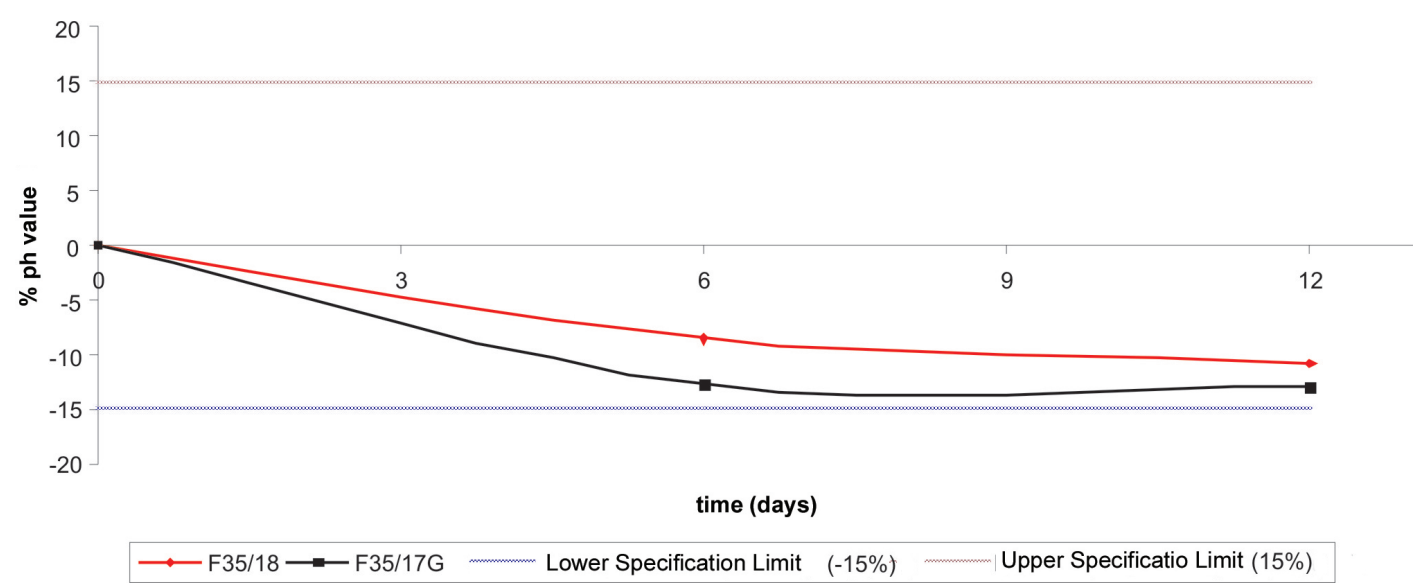

FIGURE 4 - Percentage variation of $\mathrm{pH}$ value for the test formulations F35/18 and F35/17G in the Freezing/Defrosting Cycles $\left(45.0 \pm 2.0^{\circ} \mathrm{C} /-10.0 \pm 1.0^{\circ} \mathrm{C}\right)$ storage condition in the Accelerated Stability Study

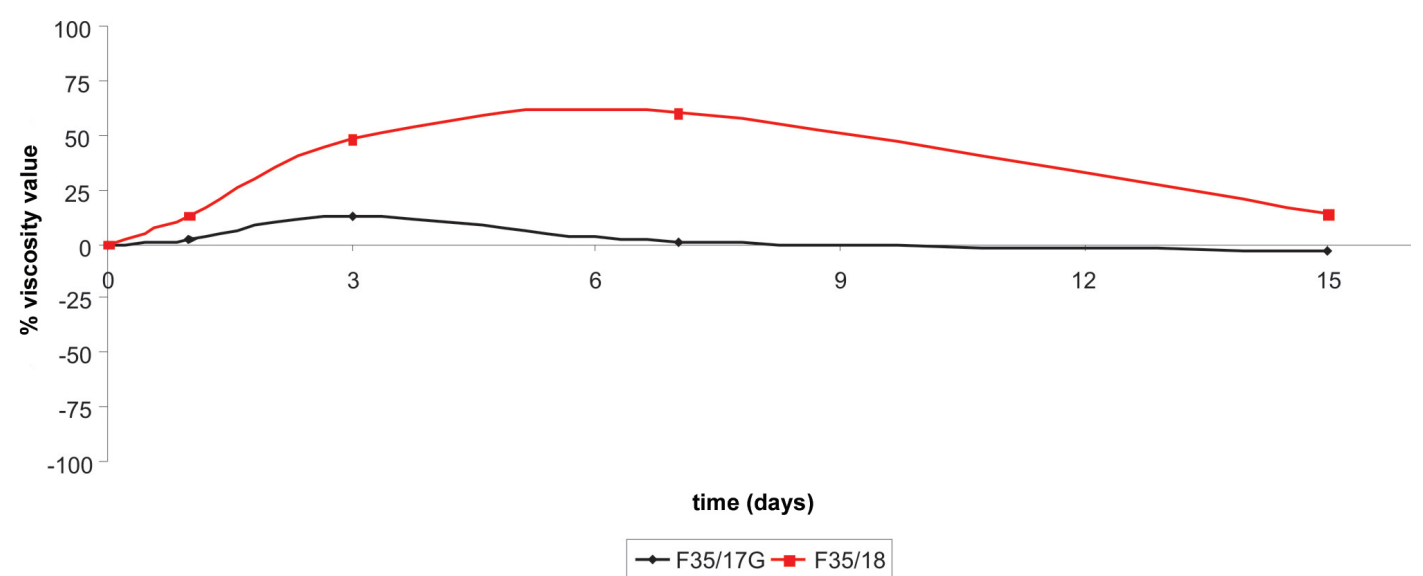

FIGURE 5 - Percentage variation of Apparent viscosity value for the test formulations F35/18 and F35/17G in the Oven (45.0 \pm $2.0^{\circ} \mathrm{C}$ ) storage condition in the Accelerated Stability Study

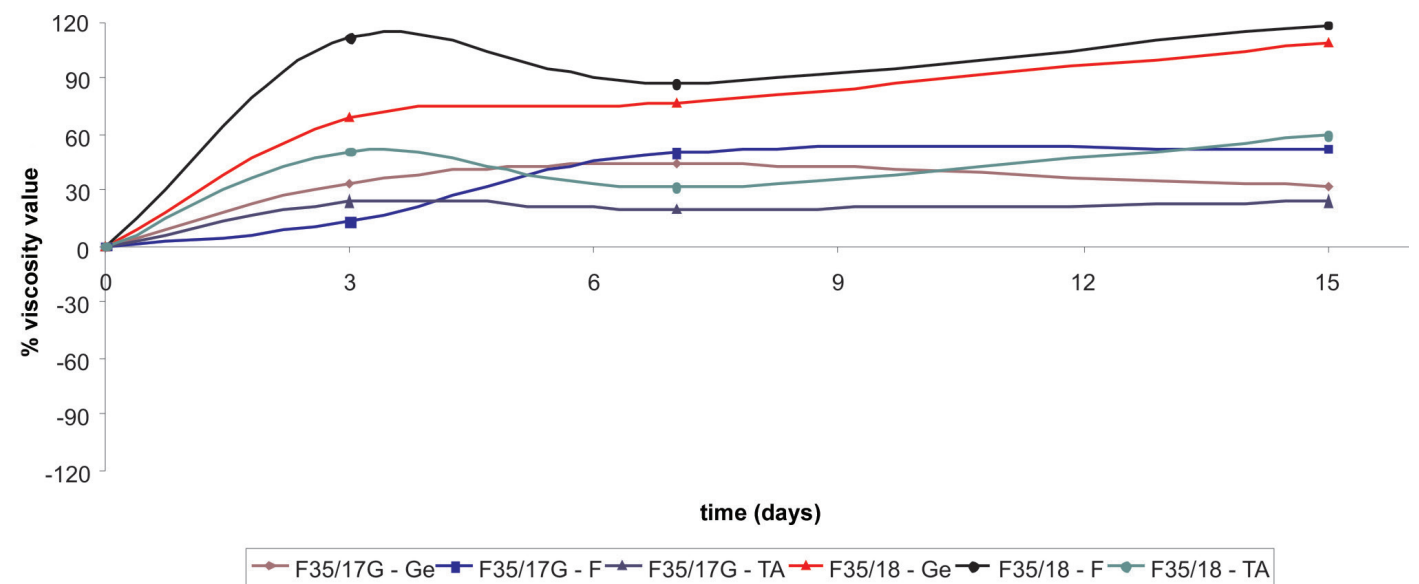

FIGURE 6. Percentage variation of apparent viscosity value for the test formulations $\mathbf{F 3 5 / 1 8}$ and $\mathbf{F 3 5 / 1 7 G}$ in the Refrigerator (Ge $\left.-5.0 \pm 1.0^{\circ} \mathrm{C}\right)$, Freezer $\left(\mathrm{F}--10.0 \pm 1.0^{\circ} \mathrm{C}\right)$ and Room Temperature $\left(\mathrm{TA}-22.0 \pm 2.0{ }^{\circ} \mathrm{C}\right)$ storage conditions in the Accelerated Stability Study 


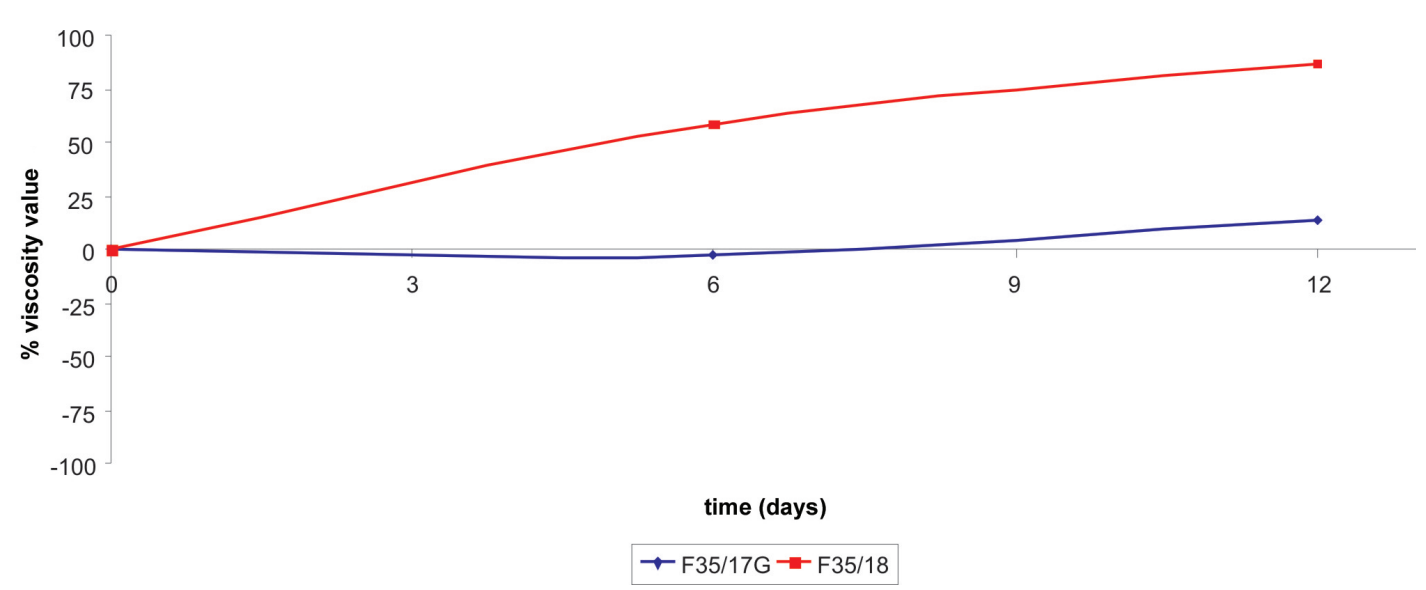

FIGURE 7 - Percentage variation of apparent viscosity value for the test formulations F35/18 and F35/17G in the Freezing/Defrosting Cycles $\left(45.0 \pm 2.0^{\circ} \mathrm{C} /-10.0 \pm 1.0^{\circ} \mathrm{C}\right)$ storage condition in the Accelerated Stability Study.
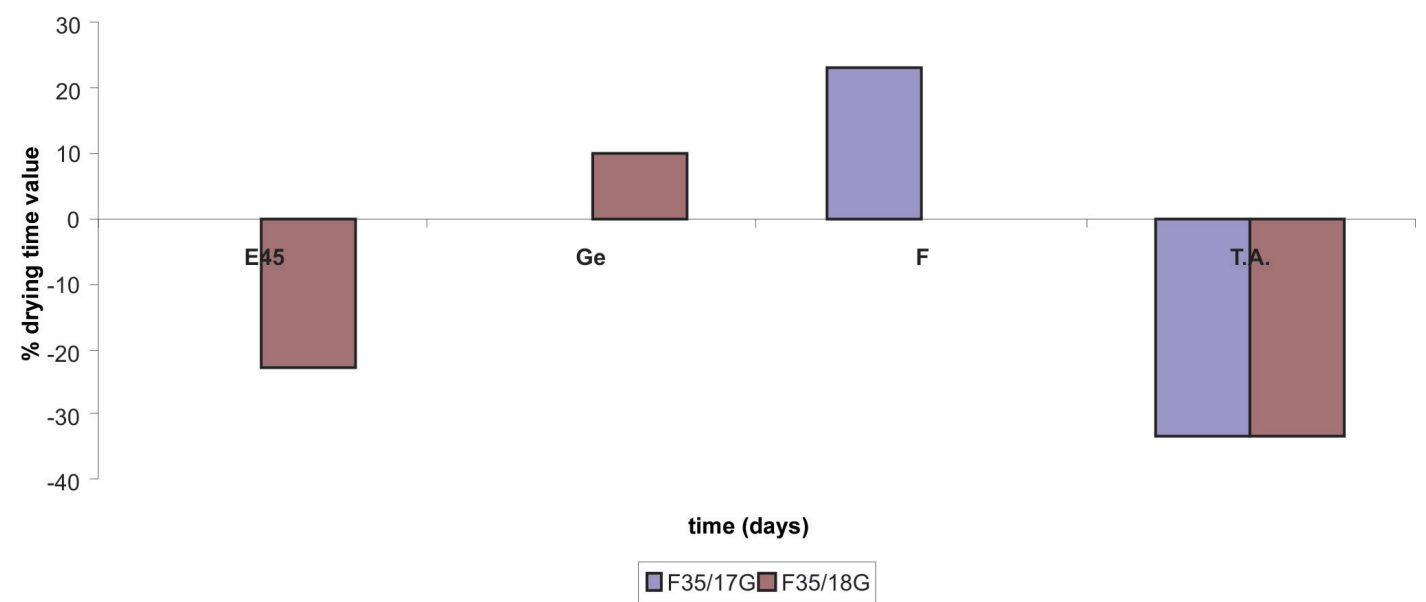

FIGURE 8 - Percentage variation of in vitro drying time for the test formulations $\mathbf{F 3 5} / \mathbf{1 8}$ and $\mathbf{F 3 5} / \mathbf{1 7 G}$ in the Oven (E45/45.0 \pm $\left.2.0^{\circ} \mathrm{C}\right)$, Refrigerator $\left(\mathrm{Ge} / 5.0 \pm 1.0^{\circ} \mathrm{C}\right)$, Freezer $\left(\mathrm{F} /-10.0 \pm 1.0^{\circ} \mathrm{C}\right)$ and Room Temperature $\left(\mathrm{TA} / 22.0 \pm 2.0^{\circ} \mathrm{C}\right)$ storage conditions in the Accelerated Stability Study. The variations are due to the difference obtained from $15^{\text {th }}$ to $t_{0}$, in all conditions.

stability, mainly in the high temperature condition and good compatibility with the used colorant. The results for Odor indicated instability manifestations at the $15^{\text {th }}$ day of Oven and Freezing/Defrosting Cycles conditions, with lowering of fragrance odor intensity and other odors not being perceptible. This response was expected since drastic conditions were employed. The evaluation of Application and Touch showed that both formulations kept the pleasant touch, with good adherence and spreadability in the Oven, Freezing/Defrosting Cycles and Room Temperature, during all time period of evaluation. It was observed that the preparations became stickier comparing to $t_{0}$ in the Freezer condition, in all days, except the formulation F35/18 that did not present modifications at the $3^{\text {rd }}$ day of test. Both preparations presented stickier and with compromised spreadability in relation to $t 0$, at the $15^{\text {th }}$ day of Low Temperature condition.
The $\mathrm{pH}$ value presented variations inside of the specifications of this research $( \pm 15 \%)$ in all conditions. In the Oven, the preparations presented similar tendency to lowering the $\mathrm{pH}$ value, being observed values until $-15 \%$ for the formulation $\mathrm{F} 35 / 17 \mathrm{G}$ at $7^{\text {th }}$ and $15^{\text {th }}$ days of evaluation (Figure 2). This reducing $\mathrm{pH}$ value profile was also observed by Nishikawa and collaborators (2007), for peel off masks developed with PVA $12.0 \% \mathrm{w} / \mathrm{w}$ and rutin $0.05 \%$, as active substance, where greater magnitude alterations in this parameter were obtained in the storage condition at $40.0 \pm 0.5^{\circ} \mathrm{C}$. These variations, for both preparations, were acceptable because of the drastic storage condition $\left(45.0^{\circ} \mathrm{C}\right)$. Furthermore, once the isoelectric point of soy proteins are within the $\mathrm{pH}$ value 4.5 - point in which proteins may precipitate -, and only values beyond the $\mathrm{pH}$ range from 2 to 10 cause degradation of proteins and isoflavonoids present in the fermented soybean extract, the chemical stability was not expected to be compromised. 
It was verified $\mathrm{pH}$ value variations lower than 5.0\% for both preparations, in the Low Temperature and Freezer conditions (Figure 3). Similarly, in the Room Temperature condition the values obtained were lower than $10 \%$ for both formulations, reaching the maximum of $-6 \%$ for the formulation $\mathrm{F} 35 / 18$ and $-7 \%$ for $\mathrm{F} 35 / 17 \mathrm{G}$ at $15^{\text {th }}$ evaluation day.

In the Freezing/Defrosting Cycles, the same tendency of decrease of $\mathrm{pH}$ value was observed over the days of evaluation for both formulations (Figure 4), which the formulation $\mathrm{F} 35 / 17 \mathrm{G}$ presented higher variations, until - $13 \%$. The same as in Oven condition, variations were expected and acceptable, inside the specific range, because of the drastic conditions that the preparations were exposed.

At the same time of $\mathrm{pH}$ value determinations, the value of apparent viscosity was also evaluated in all Accelerated Stability Study conditions. In the Oven condition (Figure 5), it was observed that the F35/18 showed variations of up to $61 \%$ in viscosity value verified at the $7^{\text {th }}$ day, while $F 35 / 17 \mathrm{G}$ showed maximum variation of $13 \%$ at the $3^{\text {rd }}$ day of test. Although it is a drastic condition, it was noticed that the preparations did not follow the same response tendency along the evaluation time of this condition.

This difference on the viscosity value variation between the formulations was observed in all storage conditions. In Low Temperature (Figure 6), F35/18 presented variations from 69 to $109 \%$, while values from 32 to $43 \%$ were verified for F35/17G. In Freezer (Figure 6), intervals from 87 to $119 \%$ were verified for F35/18, while F35/17G did not present values higher than 52\%. In the Freezing/Defrosting Cycles (Figure 7), the maximum obtained was $82 \%$ at the $12^{\text {th }}$ day of evaluation for F35/18, while for F35/17G it was $14 \%$. Finally, in Room Temperature (Figure 6), where the peel off facial masks are usually commercialized, a maximum variation of $59 \%$ in the viscosity value was verified for $\mathrm{F} 35 / 18$ formulation, at the $15^{\text {th }}$ day of evaluation; for $\mathrm{F} 35 / 17 \mathrm{G}$, the maximum verified in the same condition and period of time was $23 \%$.

The performance evaluation is determined through the in vitro drying time. In the Accelerated Stability Study, the value variations were evaluated after exposure to the conditions Oven, Low Temperature, Freezer and Room Temperature (Figure 8). It was performed at the $15^{\text {th }}$ day of each condition, the percentage variation in relation to the value obtained in to for the formulations.

No variations for the in vitro drying time were observed for F35/17G in the Oven and Low Temperature and for this reason, there was no graphical sign presented in Figure 8. For the same conditions, $\mathrm{F} 35 / 18$ presented variations of $-23 \%$ and $10 \%$, respectively. The F35/17G formulation had $23 \%$ in Freezer, while no variation was verified for F35/18 in the same condition. Both formulations presented variation of $-33 \%$ in Room Temperature.
Considering the results obtained for drying time and the organoleptic characteristics evaluation, $\mathrm{pH}$ and apparent viscosity value, it was considered that, between the F35/18 and $\mathrm{F} 35 / 17 \mathrm{G}$ formulations, the second one presented greater stability in the performed tests, associated to small variations in the in vitro drying time, in comparison to $\mathrm{F} 35 / 18$, being the $\mathrm{F} 35 / 17 \mathrm{G}$ indicated for cosmetic use.

\section{CONCLUSIONS}

The $\mathrm{F} 35 / 17 \mathrm{G}$ peel off facial mask formulation, containing $5.0 \% \mathrm{w} / \mathrm{w}$ of soybean extract fermented by $\mathrm{Bi}$ fidobacterium animalis, $17.0 \% \mathrm{w} / \mathrm{w}$ of polyvinyl alcohol and $0.5 \% \mathrm{w} / \mathrm{w}$ of guar gum was selected, from the eight (8) formulations evaluated, in the Preliminary and Accelerated Stability Studies. This formulation showed stability for the organoleptic characteristics, $\mathrm{pH}$ and apparent viscosity values and in vitro drying time. It is recommended to keep the formulation under refrigeration $\left(5.0 \pm 1.0^{\circ} \mathrm{C}\right)$ to assure lower variations in the drying time and other variables analyzed, in accordance with the observed during the stability study.

\section{REFERENCES}

ARANHA, I.; LUCAS, E. Poli (álcool vinílico) modificado com cadeias hidrocarbônicas: avaliação do balanço hidrófilo/ lipófilo. Polímeros: Ciência e Tecnologia(verificar o título não há indicação de registro ISSN), v.11, n.4, p.174-181, 2001.

BABY, A. R. Desenvolvimento e avaliação da estabilidade de formulações cosméticas anticelulíticas contendo o extrato comercial de Trichilia catigua Adr. Juss (e) Ptychopetalum olacoides Bentham, padronizado em flavonóides totais. São Paulo, 2005. 159 p. [Dissertação de Mestrado. Faculdade de Ciências Farmacêuticas. Universidade de São Paulo].

BABY, A.R.; HAROUTIOUNIAN-FILHO, C.A.; SARRUF, F.D.; TAVANTE-JÚNIOR, C.R.; PINTO, C.A.S.O.;ZAGUE, V.; AREAAS, E.P.G.; KANEKO, T.M.; VELASCO, M.V.R. Estabilidade e estudo de penetração cutânea in vitro da rutina veiculada em uma emulsão cosmética através de um modelo de biomembrana alternativo. Rev. Bras. Cienc. Farm., v.44, n.2, p.233-248, 2008.

BABY, A.R.; MIGLIATO, K.F.; MACIEL, C.P.M.; ZAGUE, V.; PINTO, C.A.S.O.; SALGADO, H.R.N.; KANEKO, T.M.; VELASCO, M.V.R. Accelerated chemical stability data of $\mathrm{O} / \mathrm{W}$ fluid emulsions containing the extract of Trichilia catigua Adr. Juss (and) Ptychopetalum olacoides Bentham. Rev. Bras. Cienc. Farm., v.43, n.3, p.405-412, 2007. 
BABY, A. R.; ZAGUE, V.; MACIEL, C.P.M.; KANEKO, T. M.; CONSIGLIERI, V. O.; VELASCO, M. V. R. Development of cosmetic mask formulations. Rev. Bras. Cienc. Farm., v.40, supl.1, p.159-161, 2004.

BAREL, A.O.; PAYE, M.; MAIBACH, H.I. Handbook of cosmetic science and technology. New York: Marcel Dekker, 2001. p.19-27.

BAUMANN, L. S.; LAZARUS, M. C. The use of cosmeceuticals moisturizers. Dermatol. Ther., v.14, n.3, p.200-207, 2001.

BONADEO, I. Cosmética ciência y tecnologia. Madri: Editorial Ciência, 1982. p.86-89.

BRASIL. Ministério da Saúde. Agência Nacional de Vigilância Sanitária, Séries Temáticas: Qualidade 1. Guia de Estabilidade de produtos cosméticos. Brasília, 2004. v.1, 45 p.

CHARLET, E. Cosmética para farmacêuticos: ciência y tecnologia. Zaragoza: Acribia, 1996. p.86-88.

CHIELlinI, E.; CORTI, A.; D’ANTONE, S.; SOLARO, R. Biodegradation of poly (vinyl alcohol) based materials. Prog. Polym. Sci., v.28, n.6, p.963-1014, 2003.

CONTRERAS, M. J. F.; SORIANO, M. M. J.; FLORES, E. S. Development of a cream from a self-emulsifying base and moisturizing actives. Farmaco, v.56, n.5-7, p.513-522, 2001.

DeNAVERRE, M. Face Masks. In: DeNAVERRE, M. The chemistry and manufacture of cosmetics. 2.ed. Orlando: Continental Press, 1975. v.3. p.421-441.

DRAELOS, Z. D. Cosméticos em dermatologia. Rio de Janeiro: Revinter, 1999. p.224-226.

GENOVESE, M. I.; LAJOLO, F. M.; BARBOSA, A. C. L. Influence of temperature, $\mathrm{pH}$ and ionic strength on the production of isoflavone rich-soy protein isolates. Food Chem., v.98, n.4, p.757-766, 2006.

LUPO, M. P. Antioxidants and vitamins in cosmetics. Clin. Dermatol., v.19, n.4, p.467-473, 2001.

MAIA, A. M. Desenvolvimento e avaliação da estabilidade de formulações cosméticas contendo ácido ascórbico. São Paulo, 2002. 117 p. [Dissertação de Mestrado. Faculdade de Ciências Farmacêuticas. Universidade de São Paulo].
MAGALHÃES, J. Cosmetologia. Rio de Janeiro: Rubio, 2000. p.82-159.

MARTINE, M. C.; CHIVOT, M.; PEYREFITTE, G. Cosmetología. Barcelona: Masson, 1995. p.81-85.

MIYAZAKI, K.; HANAMIZU, T.; IIZUKA, R.; CHIBA, K. Genistein and Daidzein stimulate hyaluronic acid production in transformed human keratinocyte culture and hairless mouse skin. Skin Pharmacol. Appl. Skin Physiol., v.15, n.3, p.175183, 2002.

NISHIKAWA, D.O.; ZAGUE, V.; PINTO, C.A.S.O.; VIEIRA, R.P.; KANEKO, T.M.; VELASCO, M.V.R.; BABY, A.R. Avaliação da estabilidade de máscaras faciais peel-off contendo rutina. Rev. Cienc. Farm. Básica Apl., v.28, n.2, p.227-232, 2007.

OTIENO, D. O.; ASHTON, J. F.; SHAH, N. P. Evaluation of enzymic potential for biotransformation of isoflavone phytoestrogen in soymilk by Bifidobacterium animalis, Lactobacillus acidophilus and Lactobacillus casei. Food Res. Int., v.39, n.4, p.394-407, 2006.

PINTO, C. A. S. O. Estudo comparativo da estabilidade de formulações cosméticas contendo papaína livre e modificada. São Paulo, 2005. 128 p. [Dissertação de Mestrado. Faculdade de Ciências Farmacêuticas. Universidade de São Paulo].

POUCHER, W. A. Poucher's perfums, cosmetics and soaps. 9.ed. London: Chapman and Hall, 1991. 751 p.

PRAKASH, D.; UPADHYAY, G.; SINGH, B.N.; SINGH, H.B. Antioxidant and free radical-scavenging activities of seeds and agri-wastes of some varieties of soybean (Glycine max). Food Chem., v.104, n.2, p.783-790, 2007.

WILKINSON, J.B.; MOORE, R.J. Face Packs and masks. In: WILKINSON, J.B., MOORE, R.J. Harry's Cosmetology. 7.ed. London: Longman Group, 1982. p.276-284.

ZAGUE, V. Desenvolvimento e avaliação da estabilidade física e físico-química de máscaras faciais argilosas. São Paulo, 2007. 160p. [Dissertação de Mestrado. Faculdade de Ciências Farmacêuticas. Universidade de São Paulo].

Received for publication on $16^{\text {th }}$ July 2008 Accepted for publication on $4^{\text {th }}$ May 2009 